\title{
New Lessons from the Old Professor
}

The finished and done with is of import as affecting the future, not on its own account: in short, because it is not, really, done with. (MW10: 10)

We do not merely have to repeat the past, or wait for accident to force change upon us. We use our past experiences to construct new and better ones in the future. (MW12: 134)

Dewey's focus on the 'reconstruction' of philosophical and political concepts of democracy was linked, as McDermott (LW11: XXV) argues, to a belief that history was a way of reconstructing the past. The meaning of history was therefore always to be refracted through the perspectives and needs of the present. With that in mind, after journeying through the work of John Dewey and his views on global democracy, it seems that we come to a logical set of questions concerning the relationship between Dewey's time and our own. How are we to use his work for our own purposes? How does Dewey's work help us contemplate and theorize our present form of globalization? And how does Dewey's work inform an analysis of post-Westphalian ideas of global democracy in the twenty-first century?

In the last chapter, I argued against the view that Dewey offered few ideas about how to achieve democracy at home and abroad through examining his views about economic equality. In this chapter, I want to push this line of thought further by outlining what I believe are the solutions Dewey offered to his own problematizing of global democracy and how we can utilize these prescient lessons within our own debates about the nature of global democracy. To highlight this, the chapter will be split into two parts. In the first part, I will outline 
four key Deweyan lessons about the problem of global democracy. These centre on the nature of society and community, the role of the nation state in furthering democracy beyond the nation state, the use of democracy at home to create a rooted cosmopolitanism and the problem of bourgeois democracy at home as the biggest impediment to global democracy. What all these lessons highlight is how Dewey believed that the problem of democracy at home needed to be tackled in order to facilitate democracy abroad. In the second part, I use these lessons to re-evaluate contemporary ideas about post-Westphalian global democracy and how Dewey's work can offer new ways of appraising global democracy.

\section{Lesson 1: A Great Society does not equal a Great Community}

One of the most galling aspects Dewey would have encountered when reading modern ideas about global democracy is how such theorists often conflate the division between society and community and neglect the implications of such a division. From a Deweyan perspective, the first lesson we can learn about global politics is to hold a healthy and historically based scepticism of narratives where our current period of globalization and advancement in modern communications technology or industrial co-operation are said to presuppose the emergence of 'communities of fate', 'transnational public spheres' or any other movement towards a global community. Whilst we may live in a globalized world, it does not automatically mean that our political ideals and identities have also become globalized. Moreover, Dewey provides a historical lesson that such globalized conditions may not necessarily lend themselves to the actual emergence of what he took to be community both on a national and on a global level. For example, Dewey outlines that:

Associated or joint activity is a condition of the creation of a community. But association itself is physical and organic, while 
communal life is moral, that is emotionally, intellectually, consciously sustained. Human beings combine in behaviour as directly and unconsciously as do atoms, stellar masses and cells... They do so in virtue of their own structure, as man and woman unite, as the baby seeks the breast and the breast is there to supply its need. They do so from external circumstances, pressure from without, as atoms combine or separate in presence of an electric charge, or as sheep huddle together from the cold. Associated activity needs no explanation; things are made that way. But no amount of aggregated collective action of itself constitutes a community ... Even if "society" were as much an organism as some writers have held, it would not on that account be society. Interactions, transactions, occur de facto and the results of interdependence follow. But participation in activities and sharing in results are additive concerns. They demand communication as a prerequisite. (LW2: 330)

This distinction between society and community held, for Dewey, not just across local and national societies but also the international associative relationships created by the advent of the Great Society. Although the associative relationships and technological advancements engendered by the Great Society created large-scale global interdependence and industrial co-operation, Dewey did not believe that such conditions alone were sufficient to create, politically and morally, a Great Community. In fact, Dewey believed technological advancements and the accompanying new habits and social customs, engendered by the Great Society's associative relationships, to actually be counterproductive to ideas of community. For instance, we have already seen that Dewey thought that the mass communication revolution (wireless telegraphs, telephones, radio) did not by default create a greater sense of community, or rather the type of communication that generated a sense of community, both within and beyond the nation state. This is even the case when the 'global' context is actively part of our daily discussions:

We cannot pick up a daily newspaper in which the word "global" does not remind us of the new situation in which we live physically, 
but without the intellectual, the educational, the moral preparation that might enable us to cope with the problems it thrusts upon us. (LW17: 454)

Dewey was adamant that a democratic community was enacted through the conscious creation of signs and symbols, habits of thought, language and action and institutions which '.. add the function of communication in which emotions and ideas are shared as well as joint undertakings engaged in' (LW13: 176). The emergence and conditions of the Great Society did not automatically lend themselves towards the creation of a Great Community but rather held the potential to facilitate such a goal. In short, the global public or rather global publics will not emerge without conscious action and the conscious dispersion of democratic habits that induce social intelligence both within and beyond the nation state. Dewey therefore provides us with the lesson that democratic communication through habits of social intelligence and the subsequent practice of creative democracy are not things that merely arise from an interdependent society, whether that be across a nation state or the globe, but rather need to be established on the back of the interdependence which arises from societal associations. ${ }^{1}$

\section{Lesson 2: The Great Community and the nation}

The discussion of forming a Great Community brings us to the question of the best means of bringing about such a Great Community and the forms of government that would serve it. One of the chief lessons of Dewey's work on the potential for global democracy is that it must include, and also arise within, the nation state. Examining Dewey's account of the Great Society, we can see that his work highlights that the collapse of modern sovereignty is actually a lot older than we care to admit. Throughout the 1920s and 1930s, Dewey continually highlighted how the interdependence of the world's nations had not only seen consequences of associated human action become transnational but also how these transnational consequences 
affected the ability of nation states to govern properly (LW11: 262). In fact, writing in 1944, Dewey mocked the idea of national sovereignty, arguing that 'something that is wholly unreal in the present state of the world' was being appealed to and employed as if it had 'significance' (LW17: 455). It was on the back of these conditions and outdated policies of nation states that Dewey constructed his own arguments for the extension of democracy globally and took to task what he saw as a bullheaded nationalism which turned indifference and antagonism into a positive virtue' in the face of such global interdependence. His subsequent conclusion was that the doctrine of national 'sovereignty', which had buttressed regressive protectionism, quests of autarky and global war, was a complete denial of the political responsibility nation states had towards one another (LW2: 376).

In the light of such statements, one might infer that Dewey would take the national political arena and nationalism to be mere transitory stages in the extension of global democracy. In this sense, the extension of democracy as a way of life would be best served by politically empowering those affected by the consequences of associated action, irrespective of nationality, through cosmopolitan law, global civil society, a transnational public sphere or supranational democratic institutions. After all, as Dewey made clear, political democracy was only effective when the 'government exists to serve its community, and that this purpose cannot be achieved unless the community itself shares in selecting governors and determining their policies' (LW2: 327). Dewey was also under no illusion that the Great Society must become a Great Community that it should be the Great Community that picks its governors.

The problem with this account, however, is whilst Dewey (LW2: 377) recognized the decline of modern sovereignty and his anti-essentialism saw him claim that 'The State is pure myth', he also understood that the loyalty of citizens to the cultural membership of the nation and its political fusion in the nation state would have to be taken seriously if global democracy was to be successful (LW15: 208-9). Dewey argued that the rise of European nationalism, which was cemented by the 
Napoleonic Wars and the resistance to foreign rule, had created a form of nationalism that consolidated 'formerly disperse political and social forces' (LW15: 208). However, this 'modern state unity' had been created not only by resistance to foreign rule but also by the Great Society's technological advancements (railways, telegraph and telephone). These technological advancements in turn created not only the aforementioned economic interdependence amongst the citizens of the nation state, but even more importantly the 'rapid and easy circulation' of opinion and information, which created a national identity beyond the face-to-face communities of people's daily lives and laid the possibility of new forms of national democratic government (LW2: 306-7). This process of cultural membership, contended Dewey, creates a national 'culture' which is exemplified in '.. ways of living so ingrained by long habituation that they form the very fibre of a people'. And as the interwar and post-world war periods had made clear, this fibre was so tough 'that it will resist, often unto death, attempts made from without to destroy it' (LW15: 208). ${ }^{2}$

At the start of the twentieth century, then, Dewey recognized what modern writers such as Anderson (1991) and Billig (1995) have pointed out, which is that nation states offer not only legal inclusion but a cultural membership that is always in the process of being remade. Such nationalism, with its exclusive and aggressive side, forms a 'conspicuous' obstacle towards global democracy. However, Dewey also noted that nationalism was 'two-sided' and that the sense of wider social order and organization provided by the nation state and its nationalism should be seen as 'positive advance' (LW15: 208-9). By this, Dewey viewed the nation state as a serious unit of social action not only because of the aggressive side of nationalism but because it was exactly one of those means which have been most expedient in the pursuit of the ethical commitment of democracy as a way of life. The nation state was therefore valuable because it was capable of upholding a national democratic community and a national practice of creative democracy.

With both sides of nationalism in mind, Dewey argued that the nation state and its institutions of democracy could not simply be 
deemed surplus to requirements or superseded but must play an active part of global democracy:

A wider community of interests cannot possibly be attained by the negative process of wiping out the communities of belief, action and mutual support which have behind them centuries of loyalty. Without a basis in them, a world government would lead a precarious existence. If such a government is to deserve the hearty support of the peoples of the earth, it must actively enlist the energies of the national states as dependable organs for execution of its politics. It can accomplish this result only as those policies give the social value of the National States a more secure opportunity to flourish than they now possess. (LW15: 209)

Whilst this belief was based on the power of nationalism and national democracy, Dewey also understood the sheer naked power of the nation state. Even within the parameters of declining modern sovereignty, given the role of the nation state in underwriting the structure of the global economy and international institutions, the nation state and, more importantly, national democracy would have to be key focal points of any global democracy. As Dewey's views on the nature of international political economy and political experiments such as the League of Nations highlight, it would simply be impossible to reform the global economy without changing the policies of powerful nation states. The lesson Dewey therefore provides here for twenty-first century observers is that global democracy, which depends on forms of transnational communication and collaboration, equally cannot function on the reification of the global at the expense of the nation state and its politics. ${ }^{3}$

\section{Lesson 3: Democracy begins at home}

A Deweyan position mandates that we take the nation state as one of the primary building blocks of any global democracy. The logical consequence of this appraisal of how global democracy could best be enacted is Dewey's subsequent lesson that national conditions of 
democracy and community are pivotal to forming a Great Community and the practice of global democracy. Moreover, Dewey suggests that without the pursuit of democracy as a way of life and the practice of creative democracy within the local community, there is little chance of the pursuit of democracy as a way of life and practice of creative democracy through social intelligence beyond the nation state:

It is said, and said truly, that for the world's peace it is necessary that we understand the peoples of foreign lands. How well do we understand, I wonder, our next-door neighbors? It has also been said that if a man love not his fellow man who he has seen, he cannot love the God whom he has not seen. The chances of regard for distant peoples being effective as long as there is no close neighbourhood experience to bring with it insight and understanding of neighbors do not seem better. A man who has not been seen in the daily relations of life may inspire admiration, emulation, servile subjection, fanatical partisanship, hero worship; but not love and understanding, save as they radiate from the attachments of near-by union. Democracy must begin at home, and its home is the neighborly community. (LW2: 368)

The above highlights two interrelated points about the role of the local and national community in the pursuit of global democracy. The first is that the local community, the one of face-to-face intercourse in institutions such as the family, school and neighbourhood, is pivotal in forming other forms of community such as a possible Great Community within the nation state and beyond. This is because it is within these daily and 'face to face' relations that the primary aspects of communication and habits of social intelligence take place. It was therefore within the neighbourly community that the ideals and practice of pursuing a democratic way of life would be taught, learned and put into initial practice. This is why Dewey said that the daily interactions and discourse between members of the local neighbourhood were the 'heart and final guarantee of democracy' (LW14: 227).

The second point is that the local is fundamentally informed and affected by the national and the international dimensions of a globalized world. The Great Society was taken by Dewey to invade and destroy 
elements of local communities and led to the immediate source of the instability, disintegration and restlessness which characterise the present epoch' (LW2: 367). Dewey was adamant that only with the reformation of local community would democracy and community be achievable both within and beyond the state:

Whatever the future may have in store, one thing is certain. Unless local communal life can be restored, the public cannot adequately resolve its most urgent problem: to find and identify itself. But if it be reestablished, it will manifest a fullness, variety and freedom of possession and enjoyment of meanings and goods unknown in the contiguous associations of the past. For it will be alive and flexible as well as stable, responsive to the complex and world-wide scene in which it is enmeshed. While local, it will not be isolated. Its larger relationships will provide an inexhaustible and flowing fund of meanings upon which to draw, with assurance that its drafts will be honoured... We lie, as Emerson said, in the lap of an immense intelligence. But that intelligence is dormant and its communications are broken, inarticulate and faint until it possesses the local community as its medium. (LW2: 370-2)

What should be noted here is that Dewey was not calling for a nostalgic return to the local democracy that was once characterized by the local 'town-meeting'. Dewey understood that the old ideas of local community town hall meetings that once animated local democracy were now outdated and unable to cope with the engendering of 'national affairs - now also affected by world affairs' (LW13: 95). Whilst Dewey argued for a reconstruction of the local community, this was to be a local community that possessed publics who were adapted to the national and global conditions of the Great Society. The regulation of the Great Society through creative democracy may have depended on a vibrant practice of democratic habits within the local community but Dewey was aware that this could only be facilitated through a national and, in turn, international form of Great Community and creative democracy. Dewey was not a nostalgic advocate of localism but an advocate of a localism now linked to and prepared for the wider world. ${ }^{4}$ 
This brought Dewey back to the problems of 'home' but this time in the guise of the national community and nation state. The reconstruction of the local community was only possible, Dewey suggested, on the back of a national form of democratic socialism and social intelligence. Furthermore, democracy beyond the state also depended on the vitality of creative democracy within the nation state:

Our first defence is to realize that democracy can be served only by the slow day by day adoption and contagious diffusion in every phase of our common life of methods that are identical with the ends to be reached and that recourse to monistic, wholesale, absolutist procedures is a betrayal of human freedom no matter in what guise it presents itself. An American democracy can serve the world only as it demonstrates in the conduct of its own life the efficacy of plural, partial and experimental methods in securing and maintaining an ever-increasing release of the powers of human nature, in service of a freedom which is cooperative and a cooperation which is voluntary. (LW13: 187)

Without citizens and publics who can comprehend the complexity and transnational nature of the Great Society and renew democracy as a way of life within the nation state, there is no chance of real political innovation beyond the nation state. The pursuit of global democracy therefore needs publics at home who could not only communicate or organize politically on a transnational basis with other publics, but who could also uphold a form of democratic community and creative democracy at home, which through the use of social intelligence would live up to the ideal of democracy as a way of life both nationally and internationally.

This reveals that Dewey's approach to global democracy was ultimately one of a 'rooted cosmopolitanism' (Bernstein 2010: 88), whereby democracy at home would be key to forging and encouraging democracy abroad. This is an approach where publics approach the global, including transnational activism, in the space of nation states and the resources and opportunities of that national context (Tarrow 2005: 42). This would entail citizens not only creating transnational 
publics but also seeing their nation state's role in the world not just as a form of moral charity but as a form of political responsibility. This form of political responsibility would include an ethical foreign policy, the use of multilateralism by their leaders to pursue social intelligence between states and an acknowledgement by nation state leaders of transnational publics (Cochran 2001: 56). Above all, however, it would require citizens within nation states to be willing to change their own habits and forms of associative action in order to provide and maintain the democratic way of life for those beyond their borders. ${ }^{5}$ As Dewey outlined when commentating on the practice of economic imperialism by US capital and the support of such imperialism by the US state, there was no chance of real political innovation in the relations between the United States and nations it held economic hegemony over without changes in policy and habits within the United States and publics within the United States who could bring such change forward:

Public opinion has spoken with unusual force and promptitude against interference in Mexico. But the causes of the difficulty, the underlying forces which make for imperialistic ventures, are enduring. They will outlast peaceful escape from the present crisis, supposing we do escape. Public sentiment, to be permanently effective, must do more than protest. It must find expression in a permanent change of our habits. For at present, both economic conditions and political arrangements and traditions combine to make imperialism easy. How many American citizens are ready for an official restatement of the Monroe Doctrine? (LW3: 162)

This view of the need to establish democracy at home in order to help facilitate democracy abroad can also be found in Dewey's thought on the school system in the midst of totalitarianism. Dewey saw the nation's school system as not just a place of training for industry, but also an underutilized arena where there could be a positive and constructive cultivation of the democratic way of life both within and beyond the nation state. Dewey believed that the school, as an institution that taught the democratic way of life, could be reformed and better utilized 
to '.. break down class division, creating a feeling of greater humanity and of a membership in a single family ...' through spreading the habits of social intelligence (LW13: 302). However, Dewey reiterated that he saw this relationship as one where such a global commitment to democracy as a way of life abroad would only be secured through democracy as a way of life at home:

What do we mean when we assume that we, in common with certain other nations, are really democratic, that we have already so accomplished the ends and purposes of democracy that all we have to do is to stand up and resist the encroachments of nondemocratic states? We are unfortunately familiar with the tragic racial intolerance of Germany and now Italy. Are we entirely free from that racial intolerance, so we can pride ourselves upon having achieved a complete democracy? Our treatment of the Negroes, anti-Semitism, the growing (at least I fear it is growing) serious opposition to the alien immigrant within our gates, is, I think, a sufficient answer to that question. Here, in relation to education, we have a problem; what are our schools doing to cultivate not merely passive toleration that will put up with people of different racial birth or different colored skin, but what are our schools doing positively and aggressively and constructively to cultivate understanding and goodwill which are essential to democratic society? (LW13: 301)

Without the realization and practical experience of what 'cooperation, goodwill and mutual understanding' looked like at home, Dewey feared that the ideas of peace that schools were doing a great deal to 'inculcate' would go little beyond 'sentimental attachment to a realisation of what peace would actually mean in the world ...' (LW13: 303). This reflection on education was, in a sense, a microcosm of Dewey's belief that democracy abroad was always linked with democracy at home. It is not just that we cannot examine the chances of global democracy without taking into consideration the status and vitality of our democracy at home, but rather that without a strong form of creative democracy at home, at both the local and national level, there will never be creative democracy away and beyond from home. This is the case even if our 
ultimate goal is to make the 'away and beyond' our 'home' in the final instance. ${ }^{6}$

\section{Lesson 4: The spectre of bourgeois democracy must be exorcised!}

A fuller appreciation of Dewey's work reveals that whilst he embraced multiple routes towards global democracy, he also believed that those routes must include the nation state and the vitality of the local and national community. This point is exemplified in the double mandate Dewey gave his call for democratic renewal within the American nation state. The democratic community within the nation state, Dewey argued, needed to become a Great Community (democratic community) that would help facilitate a Great Community beyond and between nation states. Only through this process would the world secure the democratic way of life for all humans and reap the benefits of social intelligence. However, this brought Dewey back to the problem of bourgeois democracy and the eclipse of the public within the nation state and how bourgeois democracy as an economic, cultural and political formation was fundamentally at odds with creative democracy within and beyond the state.

The main problem that Dewey identified with bourgeois democracy and its influence on global democracy is that the material and cultural inequalities engendered by liberal capitalism are the product of the hegemonic cultural ideas of liberal capitalism (individualism, liberty, profit), which are antithetical to the spread of democratic habits of social intelligence within the nation state. This was confined not only to the level of the nation state but at the international level, where the doctrine of liberal capitalism and free trade between states underpinned a regime of imperialism and inequality between the global North and South. However, Dewey pushes beyond simply equating the culture of liberal capitalism as being incompatible with creative democracy at home and abroad by positing a fundamental 
relationship between the lack of democracy at home and the lack of democracy abroad.

Moreover, Dewey highlights how the hegemony of the tenets of liberal capitalism and the perpetuation of high levels of material and intellectual inequality within nation states, what Dewey called bourgeois democracy, often bred an anti-cosmopolitan nationalism and the rejection of greater democracy and co-operation at the international level amongst citizens and their governments. This is why Dewey was adamant that it was the eclipse of the public and the breakdown of creative democracy at a national level that explained the lack of global democracy. Dewey therefore extends his narrative of the collapse of community and democracy at the local and national level into the narrative of why the democratic community and creative democracy are absent abroad. The lesson Dewey provides here is that democracy abroad fails due to the same reason democracy at home fails: the eclipse of the public engendered by the cultural and structural inequalities of bourgeois democracy.

Dewey's reflection on the relationship between bourgeois democracy and global democracy therefore outlines his thinking on the relationship between liberal capitalism and democracy. This pivots on Dewey's belief that the ideas and virtues of liberal capitalism are fundamentally unable to support democracy at home or abroad. To this end, the cultural hegemony of the former must be tackled in order to facilitate the emergence of the latter. We have, of course, seen that Dewey was adamant that without the provision of democratic knowledge and habits facilitating social intelligence within social institutions, such as political democracy and education, there was little to no chance of creative democracy at the national level and smaller chance of creative democracy beyond the state. However, Dewey's overriding message was that for the above to happen there must be a fundamental reorganization of liberal capitalism and its ideas of individualism and liberty. This, as we have seen, was Dewey's argument for the extension of a form of democratic socialism and egalitarianism both at home and abroad. ${ }^{7}$ 
This reflection on the incompatibility of liberal capitalism and democracy and its effects on hopes for democracy beyond the state has knock-on effects on how we should judge Dewey's idea that democracy abroad would only be truly effective on the basis of democracy at home. Dewey's perspective of the nation state as a key vehicle for global democracy translates into the view that we cannot disconnect the current state of national democracy, or a lack of national democracy within bourgeois democracy, from the issues of forming a Great Community and practising creative democracy both within and beyond the state. Although Dewey (LW5: 442) claimed that national democratic practices and institutions had become the 'the errand boys' of a 'privileged plutocracy' and were inflexible and uncreative under the hegemony of bourgeois democracy, it was nevertheless:

... sheer defeatism to assume in advance of actual trial that democratic political institutions are incapable either of further development or of constructive social application. Even as they now exist, the forms of representative government are potentially capable of expressing the public will when that assumes anything like unification. (LW11: 60)

The analytical lesson Dewey provides is that the interconnection between the auspices of bourgeois democracy and the possibility of global democracy is exactly why political democracy at home cannot simply be transcended or deemed unimportant when examining global democracy. Quite simply, the issue of who controls the nation state and its institutions and whose interests it serves are too important to the founding of a Great Community and the practice of creative democracy internationally:

The dominant issue is whether the people of the United States are to control our government, federal, state and municipal, and to use it in behalf of the peace and welfare of society or whether control is to go on passing into the hands of small powerful economic groups who use all the machinery of administration and legislation to serve their own ends. (LW6: 149) 
Dewey believed that democratic renewal at home must include a reorganization of both the politics and political economy of bourgeois democracy. This demanded the re-emergence of publics within nation states from their perpetual eclipse in the face of the Great Society and their use of creative democracy through the lens of social intelligence. However, this also demands publics who see that only radical reform of the political economy of bourgeois democracy will facilitate such change (LW11: 298-9).

This reveals Dewey's final lesson on the fate of global democracy in the midst of the Great Society. The renewal of democracy at home demanded the guarantee of the ethical commitment of the democratic way of life and the practising of creative democracy through a community of citizens who possessed the habits of social intelligence. Without such democratic renewal at home and the use of the nation state to pursue a form of rooted cosmopolitism, it would be impossible, Dewey argued, to achieve the change needed within the international sphere to guarantee the democratic way of life. The chief point, however, is that such a renewal of democracy at home would be half-hearted and unable to secure creative democracy at home or abroad without the political and cultural reorganization of bourgeois democracy at home and the aspiration to effect change in the global liberal-capitalist economy. It was Dewey's hope that America would heed these words and embark upon such a renewal of democracy at home that would provide the conditions for America to help bring about creative democracy abroad:

With our fortunate position in the world I think that if we used our resources, including our financial resources, to build up among ourselves a genuine, true and effective democratic society, we would find that we have a surer, a more enduring and a more powerful defence of democratic institutions both within ourselves and with relation to the rest of the world than the surrender to the belief in force, violence and war can ever give. (LW13: 302-3)

This should be seen as the final element in Dewey's lessons on the relationship between local and national community and the hopes of forging the Great Society into a Great Community both at home and 
abroad. Having identified that communities are conscious constructions rather than automatically arising out of societal relations, and that the nation state represented a form of political power and sense of community that could not be easily discarded, Dewey naturally shifted to examining how the politics of the nation and its idea of democratic community could help facilitate democracy beyond the state. This not only required the formation of a democratic community and social intelligence at home but came with a warning that global democracy would be bound to fail without the economic, cultural and political exorcism of the spectres of bourgeois democracy that haunted the Great Society. ${ }^{8}$

\section{Global democracy: A new name for an old problem}

John Dewey died in 1952, and his hopes for greater global democracy have remained largely unfulfilled throughout the late twentieth and early twenty-first centuries. ${ }^{9}$ However, as prior work on his international thought has shown, it is quite easy to see Dewey as the great resolver of the dualisms that plague the theorizations of global democracy. We can therefore herald Dewey as providing an approach to global democracy that challenges the dualisms between top-down and bottom-up approaches to post-Westphalian global democracy, and between statist and post-Westphalian democracy. Dewey believed in not only macro-reform of international institutions and global governance through a reformation of state relations but also bottomup processes of publics uniting across the global contours of the Great Society. These ideas not only prefigure an increased role for global governance institutions, such as the UN's responsibility for human security and networks of state special agencies, but also call for an international public sphere of citizens, activists and social movements. Dewey can therefore be seen as an early advocate of the management of international interdependence through the multiple routes of state and non-governmental institutions and practices (Cochran 2010: 323-8). 
This take on Dewey's approach to global democracy is superficially correct: the dualisms between top-down and bottom-up ideas of global democracy, and statist and post-Westphalian approaches to global democracy are simply unsustainable. However, this narrative still does not reveal the fullest expression of Dewey's approach to global democracy and how he fundamentally believed the problem of bourgeois democracy at home impacted on democracy abroad. The key lesson of Dewey's work for ideas about global democracy is that whilst a rejection of statist conclusions about global democracy is correct, the importance of the nation state and the status of its democracy and community cannot be discounted within non-statist formulas. Dewey understood that without changes at the national level and in particular its bourgeois democracy, which itself could be helped through transnational communication and collaboration, democracy beyond the state would be hampered and ineffective. Dewey's rooted cosmopolitanism was therefore just that: the strong roots of democracy at home supported the crown of democracy abroad.

This is not the unmasking of Dewey as a proxy statist who dismissed the importance of transnational and non-governmental spaces, such as global civil society and regional or global political forums. As we saw in Chapter 2 and highlighted at the start of this chapter, Dewey can be seen as a thinker who would breach the dualism between state and post-Westphalian positions and between top-down and bottom-up approaches to global democracy. Moreover, his evocation of global civil society reflected his belief that citizens and publics could increase their participation in global democracy through voluntary organizations rather than just investing their hopes of global democracy in national governments or other forms of bureaucracy (Cochran 2010: 327). This would be equally important in the formation and conduct of international institutions, which without the input of the masses of the world would end up as elitist arenas dislocated from the concerns of common humanity. However, Dewey believed that such tactics could only be piecemeal or marginally successful if publics within the nation 
state did not support such causes and eventually achieve change at the national level.

Dewey would have undoubtedly supported the use of global civil society and transnational forms of activism and communication that use 'boomerang' (Keck and Sikkink 1998) tactics to reach out from local sites to global arenas in order to reverberate back on national policy. Such forms of transnational activism and communication would offer the signs and symbols needed to create elements of community beyond the national context. This today would be what modern writers call transnational coalition formation between publics across borders (Tarrow 2011: 255). This assertion is strengthened by Dewey's own participation in such forms of activism as the Outlawry for War Movement, the Council for a Democratic Germany, the League of Free Nations and the American Friends for Spanish Democracy (Cochran 2010: 310). However, the American base of such activism highlights Dewey's view that without the power of the nation and the vitality of the democratic community, at both the local and national level, there was little chance of democracy beyond the nation state. Dewey's 'rooted cosmopolitanism' therefore reflects the term's modern usage whereby the conduct of global or transnational politics is always domestically rooted (Appiah 1996, 2005: 213-72).

Indeed, contemporary conditions would seem to highlight the continuing saliency and purchase of Dewey's appraisal of global democracy. Writers such as Tarrow (2011: 257) point to fact that 'it has become clear - if it was ever unclear' at the dawn of the twenty-first century, with American military power and government action to tackle the 2008-2009 financial crisis, 'that the power of states is not going to disappear in short order'. Those sceptical of the economic reality of globalization, for example, point to the persistence of nation state power within the confines of neo-liberal globalization and its effects upon modern sovereignty (Mosley 2005; Hay 2007; Hirst et al. 2009). These authors argue that the nature of the flow of trade, investment and finance reveals that the world economy is not global but rather a highly 'internationalized' economy separated into a triad of trade blocs 
(Europe, East Asia and North America). Whilst this has changed the nature of global North/South relations, where select nations in the global South have produced miraculous economic growth through exports for consumption zones in the North, the reality is still a highly uneven and unequal global economy largely controlled by and for the global North. This is compounded by the reluctance of hegemonic Western nation states, even in the face of rising Southern powers such as Brazil, China and India, to cede their power within international institutions, such as the UN, IMF and World Bank, and help facilitate greater democracy at the international level (Wade 2013).

In fact, even the runaway world that is neoliberal globalization can be regulated towards democratic ends by nation states. For instance, Hirst et al. (2009) argue that the major economic powers of the G8, China and India have the capacity, if they were to coordinate multilaterally, to bring about greater democratic governance over financial and other international economic practices. However, the current scope of such governance is constrained by the interests of the major economic powers and the hegemony of neo-liberalism amongst political and economic elites (Hirst et al. 2009: 3; Weiss 2009). This viewpoint has gained even more credence in the light of the 2008 financial crisis and the onset of the Great Recession, where the power of the state to intervene in global markets and reform the international order has been shown to outrank international institutions and forums such as the UN, the IMF and the Basel Committee on Banking Supervision (Rodrik 2012). This would seemingly make nation state politics the key for any form of global democracy and is corroborated by the fact that the majority of citizens still predominately value their national identity over other allegiances and see their national governments as the primary providers of public goods (Rodrik 2011; Tarrow 2011).

Concurrently, our present forms of national political democracy are said to be in crisis (Hay 2007). This pivots on the collapse of post-war social democracy and the rise of neo-liberalism, which has engendered large-scale wealth inequality and the hegemony of finance capitalism over the state, its elites and citizens (Stiglitz 2010, 2012; Englen et al. 
2011; Wade 2012). This has seen the stagnation of political democracy within the nation state, where national politicians and elites have underwritten globalization and effectively outsourced, renounced or relinquished elements of their political power over to global markets. Concurrently, wealthy citizens whose interests are served by such an ideology find great ease in bending the ear of government to their interests (Gilens 2012). Neo-liberalism's 'atomisation of society, citizens, and classes' has brought forth a mass public who are now 'consumers of goods or information' and have more trust in the Internet than their political representatives (Mazower 2012: 425-6).

Does any of this sound familiar? Our current situation is based upon rich Western nation states who control the global economy and international institutions in their interests; the hegemony of economic liberalism and its idea of economic liberty within international and domestic political contexts; the control of national democratic structures by wealthy citizens and the persistence of largescale inequality within state; and the continuing pull of nationalism for modern citizens within nation states even in the midst of the breakdown of trust between a large sway of those citizens and their respective governments. Even though there has been so much change since Dewey's death, one could not paint a better picture of the hegemony of liberal capitalism over democracy at the international level and the persistence of bourgeois democracy at home. ${ }^{10}$ At the start of the twenty-first century, the regime of liberal capitalism and bourgeois democracy is still partying like it was $1929 !^{11}$

With these facts in mind, the clamour for post-Westphalian global democracy appears more like an evasion rather than a confrontation of this reality (Chandler 2010). This conclusion becomes even more apparent when one considers the reactions of advocates of postWestphalian global democracy to the failure to secure adequate forms of global democracy. For example, Hale et al. (2013) see greater global democracy facing 'gridlock' in the aftermath of the 2008 financial crisis and in response to global problems such as climate change. This is to be explained as the result of growing multipolarity and politicians privileging national over global interests. Habermas (2012) and Beck 
(2013) find the Eurozone crisis to be a political rather than economic problem, which stems from national and European elites perpetuating forms of 'post-democratic bureaucratic rule' and the lack of a European identity and public sphere amongst the citizens of European nation states. Bottom-up advocates such as Dryzek (2012) point to the inability of global civil society to achieve significant change at the international level and argue that this reveals the different nature of democracy at the global level in contrast to democracy at the national level.

In seeming to ignore the realm of national democracy in order to argue for global forms of democracy that transcend the state, these authors fail to register how the crisis of democracy at home influences the crisis of democracy abroad. For example, the gridlock facing global multilateralism is not simply a case of growing multipolarity or nationalism amongst politicians but also the hegemony of neoliberalism amongst political elites, anti-cosmopolitanism at home and the fact that countries in the global North are unwilling to cede power within international institutions. The same could be said for the neoliberal settlement that is currently being sought within the Eurozone, where national politicians from northern European countries and elites within institutions, such as the European Central Bank and the IMF, appear to be defending the interests of European finance capital by enforcing austerity on southern European countries (Blyth 2013). This state of affairs remains unchallenged because, as Dryzek (2012) himself laments, the political power associated with global democracy from below is incapable of holding governments to account on such issues.

National democracy and its vitality, as Dewey suggests, is one of the keys to global democracy. Why, for example, are citizens not currently forcing their national representatives to pursue greater multilateralism and cede power at the international level? Why are citizens in northern European states not forcing their governments to back the interests of Europe's citizens rather than its finance capital? Why are global issues such as climate change not key issues for national publics? It is beyond the focus of this present study to offer a full-blown empirical examination 
of these events but it is safe to say that the answers or at least a large part of the answers to such questions would seemingly revolve around the hegemony of bourgeois democracy and the eclipse of national publics, who are unable to force their political representatives to pursue the democratic way of life both at home and abroad. Moreover, Dewey's work reflects the work of modern writers such as Bandy and Smith (2005: 293, cf. Smith 2008), who upon surveying transnational politics have concluded that the success of global democracy must '... rely on well-established national or local movements' Yet, this perspective is lost in translation when post-Westphalian positions underplay the role of the state and national democracy in the formation of global democracy as a result of the obvious failures of statist positions.

From a Deweyan perspective, the challenge for conceptualizations of global democracy must be to overcome the failings of post-Westphalian ideas of global democracy without having recourse to statist solutions. Rather than abandoning the realm of national democracy and the nation state as defunct political spaces, we must examine the interplay between the present regime of bourgeois democracy at home and the hopes and practice of democracy beyond the nation state. This opens up questions such as: How are our educational and wider cultural practices facilitating global democracy through creating a rooted cosmopolitanism? How are xenophobia and anti-cosmopolitan attitudes linked to income inequality and democratic disillusionment at home? What are the politics and policies through which we can help rediscover the radical faith in democracy and bring forth publics which can exorcise bourgeois democracy at home and abroad? And how is this process helped or hindered by the machinations of globalization and forces outside the state?

These are questions that go beyond mere academic reflection and conjoin with the need for democratic renewal through political activism at the local and national level. As Dewey and his own activism of the 1930s remind us, we must fight for democratic renewal at home to help facilitate democratic renewal abroad. However, what is clear is that the nature, political efficacy or viability, of any conception of 
'global democracy' in the twenty-first century can only be adequately conceptualized by revisiting and confronting Deweyan concerns about the political efficacy or viability of publics and their relation to democratic praxis within the nation state. Contrary to post-Westphalian positions on global democracy, the problems of democracy within the nation state cannot be avoided or transcended simply by taking democracy to transnational or global dimensions. Indeed, to phrase the problem in this manner is to miss Dewey's point altogether that without democracy at home there is very little chance of democracy abroad. 